\title{
Mermer Ocaklarında Kullanılan Zincirli Kesme Makinelerinin Performansının Araştırılması
}

\author{
Muhammed Ali ÇALIŞKAN*1, Hüseyin YAVUZ² \\ ${ }^{1}$ Mardin Özel Harekât Şube Müdürlüğü, 47200, Mardin \\ ${ }^{1}$ (ORCID: https://orcid.org/0000-0001-8467-9660) \\ ${ }^{2}$ Süleyman Demirel Üniversitesi, Mühendislik Fakültesi, Maden Mühendisliği Bölümü, 32260, Isparta \\ ${ }^{2}$ (ORCID: https://orcid.org/0000-0003-2728-7374)
}

(Alınış / Received: 17.05.2018, Kabul / Accepted: 20.12.2018, Online Yayınlanma / Published Online: 12.03.2019)

\begin{abstract}
Anahtar Kelimeler
Mermer blok üretimi, Zincirli kesici,

Kesim parametreleri,

Kesim performansı
\end{abstract}

\begin{abstract}
Özet: Bu çalışmada, mermer ocaklarında blok üretimi amacıyla kullanılan zincirli kollu kesme makinelerinin kesim performansları araştırılmıştır. $\mathrm{Bu}$ amaç doğrultusunda, öncelikle dört farklı ocakta kullanılan kollu kesim makinelerinin özellikleri, keskilerin tipi ve keski düzeni incelenmiștir. Her bir ocakta kesimde zincir dönüş hızı ve makine yürüyüş hızı gibi parametreler değiștirilerek birim zamanda kesilen yüzey alanları ölçülmüştür. Makinenin kesim hızı, zincir hızı, keski seti uzunluğu ve kol kesme açısı gibi parametrelere bağlı olarak keski seti kesme derinliği hesaplanmıștır. Kesim parametrelerinin kesim performansına etkisini incelemek amacıyla, kesim sonrasında çıkan pasadan toz numuneler alınarak elek analizleri yapılmış ve pasa irilik indeksleri belirlenmiştir. Ayrıca çalışma yapılan doğaltaşların laboratuarda bazı fiziko-mekanik özellikleri belirlenmiştir. Çalışmanın sonucunda, 4 farklı ocakta kullanılan zincirli kesicilerin verimli çalışması için optimum çalışma parametreleri önerilmiştir.
\end{abstract}

\section{Investigation of the Performance of Chain Saws Used in Marble Quarries}

\author{
Keywords \\ Marble block production, \\ Chain saw, \\ Cutting parameters, \\ Cutting performance
}

\begin{abstract}
In this study, the cutting performance of the chain saw machines used for block production in marble quarries was investigated. For this purpose, firstly, the specifications of the chain saw machines used in the four different quarries, type, and sequence of cutting tools are examined. In each quarry, the areal cutting rates were measured by changing the parameters such as arm pressure and chain speed during the cuttting. Cutting depth of cutting tool sequence is calculated according to parameters such as machine cutting speed, chain speed, length of cutting tool sequence and angle of cutting arm. In order to investigate the effect of cutting parameters on cutting performance, sieve analyzes were carried out by taking dust samples from each cut pile and grain size indexes were determined. In addition, some physical and mechanical properties of natural stones were determined in the laboratory. As a result of this study, optimum working parameters are proposed for the efficient operation of chain sawing machines used in 4 different quarries.
\end{abstract}

\section{Giriş}

Mermer ocak ișletmeciliği, uygarlık dönemlerinin ilk tarihlerinde başlamış, temel prensipleri değişmemekle beraber, yüksek üretim kapasitelerini sağlayan mekanizasyonun bu alana gelmesiyle günümüzdeki şeklini almıştır. Mermer ocaklarında kullanılan başlıca üretim yöntemleri; oluk-kanal açma, delik delme-üçlü kama, helezon tel kesme, elmas tel kesme, zincirli kesicilerle kesme, elmas disk kesicilerle kesme, termal şok (rock jet), basınçlı su (water jet), lazer ışınları ile kesme ve karma üretim yöntemleridir. Tüm ocaklar günün teknolojik koşullarına göre tel kesme yöntemini kullanırken uygun özellik taşıyan ocaklarda da zincirli kollu kesicilerle blok üretimi yapılmaktadır [1].

Zincirli kesme makineleri düşük veya orta dereceli aşındırıcı olan mermer ve traverten gibi yumuşak ve orta sert doğal taşların, hem açık ocaklarda hem de yeraltı ocaklarında blok olarak çıkarılmasında ve sayalama amacı ile düşey veya yatay kesim yapmada 
kullanılabilmektedir [1]. Zincirli kesme makinesi ana üniteleri Şekil 1'de verilmiștir.

Zincir dönüşü ve araba hareketi, bir elektrik motoru ile tahrik edilen 2 ayrı hidrolik motor vasıtasıyla sağlanır. Sistem üç ana üniteden oluşmaktadır: Kol/biçak, ray sistemi ve ana gövde ve kumanda panosu. Ana gövde ray üzerinde hareket ederken kol ve üzerindeki kama tipi keskiler yardımıyla kesme işlemi gerçekleştirilir. Kol uzunlukları 9 m'ye kadar olabilmektedir. Kolun kesme dilim kalınlığı üretici firmaya bağlı olarak $42 \mathrm{~mm}$ (en yaygın) veya $38 \mathrm{~mm}$ olabilmektedir [1].

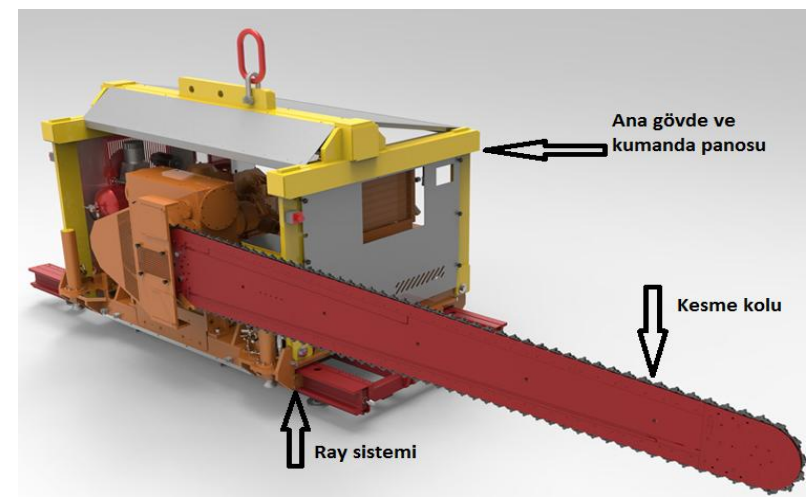

Şekil 1. Zincirli kesme makinesi ana üniteleri [2].

Zincirli kesme makinelerinin avantajları:

- Özellikle 6-7 m’den yüksek basamaklarda elmas boncuklu tel kesme makineleri ile birlikte kullanıldıklarında, tel geçirmek için gereken delik sayısını azaltarak zamandan ve işçilikten tasarruf sağlar. Diğer bir değişle, delik çakıştırma problemini ortadan kaldırır.

- Yeni bir basamağa yatay veya düşey olarak kolaylıkla giriş yapabildikleri ve üçgen parça kesme işlemini ortadan kaldırdıkları için üretim ve zaman kayıplarını azaltırlar.

- Doğrudan satılabilir ürün çıkarabilirler.

- Oldukça düzgün yüzeyler oluşturdukları için mükemmel çalışma ortamı oluştururlar.

Literatürde mermer ocaklarında kullanılan zincirli kollu kesme makineleriyle ilgili çok fazla çalıșmaya rastlanılamamaktadır. Önenç ve Demirocak, yaptıkları çalışmada tabaka duruşlarına göre blok kesim yöntemlerini inceleyerek tabaka kalınlıkları fazla olmayan, mohs sertlik skalasına göre sertlikleri 3-4 arasında bulunan, albenisi fazla olan kayaçların kesimlerinde zincirli kesiciyi kullanmanın iyi sonuçlar verdiğini ifade etmişlerdir [3]. Çopur vd., yaptıkları çalışmada zincirli kesme makinelerinin düşük veya orta dereceli aşındırıcı olan mermer ve traverten gibi yumuşak ve orta sert doğal taşların, hem açık ocaklarda hem de yeraltı ocaklarında blok olarak çıkarılmasında ve sayalama amacı ile düşey veya yatay kesim yaparak kullanılabileceklerini söylemișlerdir. Elmas boncuklu tel kesme makineleri ile birlikte kullanıldıklarında (bu yaygın kullanım şeklidir) ocak verimini artırdıklarını ve bir traverten açık ocağında kullanılan elmas boncuklu tel kesme makinelerinin yanına sadece bir adet zincirli kesme makinesi ilave edilerek, ocağın genel veriminin \%20 arttığını açıklamışlardır [4]. Demirel vd., yaptıkları çalışmada yerli ve yeni imalat olan Kollu Zincirli Kesme makinesinin (DZK-3400), Denizli Kaklık/Kocabaș traverten ocaklarında deneme uygulama sonuçlarını değerlendirmişlerdir. Doğaltaş ocak işletmelerinde blok üretim verimliliğinin artırılması ve blok üretim kalitesinin yükseltilmesine yönelik elmas tel kesme yöntemine alternatif olarak, kollu zincirli kesme makinesinin yeni bir yöntem olarak denemelerini gerçekleştirmişlerdir. Başta traverten ocakları olmak üzere tüm doğaltaş ocaklarında kullanımı ile birim zamanda daha az maliyetle daha fazla blok üretimi gerçekleştirmesini amaçlamışlardır [5]. Ayrıca mermer ocaklarında kollu zincirli kesme makinesinin uygulanabilirliğini elmas tel kesme makinesi ile karşılaştırarak açıklamışlardır [5].

Çopur vd., yaptıkları çalıșmada, doğal tașların blok olarak kesilmesinde kullanılan zincirli kesme makinelerinin performanslarını etkileyen makine ve doğal taş parametrelerini incelemişlerdir. $\mathrm{Bu}$ makinelerin çeşitli doğal taşlarda daha verimli çalışabilmelerini sağlayacak verimli kesme prensiplerini ortaya koymuşlardır. Bu amaçla, ilk önce çeşitli doğal taş üretimi yapan ocaklara gidilmiş ve arazide jeolojik koşullar, zincirli kesme makinelerinin özellikleri ve çalışma (işletme) parametrelerini belirlemișler, kullanılan zincirli kesme makinelerinin performanslarını (kesme-kazı hızları) elektronik ortamda kaydetmişler, keski aşınma şekillerini incelemişler ve gözlem-ölçüm yapılan yerlerden blok numuneler almışlardır. Alınan blok numunelerini laboratuarda bir seri deneye tabi tutmuşlardır. Doğrusal kazı deney setinde $0^{\circ}, 15^{\circ}, 30^{\circ}$ ve $45^{\circ}$ yanal açıları olan keskiler çeşitli kesme koșullarında (kesme derinliği, keskiler arası mesafe, vs) kesilerek, numunelerin kazılabilirliklerini (keski kuvvetleri, spesifik enerji, optimum kesme geometrisi) ortaya koymuşlardır. Fiziksel ve mekanik özellikleri belirlemeye yönelik olarak, tek eksenli basınç dayanımı, çekme dayanımı, shore scleroscope sertliği, Schmidt çekici sertliği, statik elastisite modülü, akustik deneyler (dinamik elastisite modülü ve poisson oranı), cerchar aşındırıcılık deneyleri ve ince kesitlerin petrografik analizlerini yapmıșlardır. Deney sonuçlarını kullanılarak, standart zincirli kesme makinelerinin çalışmasını simule eden deterministik bir bilgisayar modeli geliştirmişlerdir. Modelin geçerliliğini sınamak için, modelleme sonuçlarını, yerinde yapılan performans kayıtları ile kıyaslamışlardır. Son olarak, kazılabilirliği ve performansı etkileyen en önemli doğal taş mekanik özelliklerini belirleyerek, makine performansları ve 
laboratuar kesme performansı ile bu parametreler arasında istatistiksel ilişkileri inceleyerek istatistiksel performans tahmin modellerini geliştirmişlerdir. Bu modellerin, zincirli kesme makinesi seçimi, tasarımı ve performans tahmininde, fizibilite/planlama aşamasında kullanılabileceğini açıklamışlardır [6].

Yeşilkaya vd., yaptıkları çalışmada Denizli havzasında Denizli Çimento Fabrikası çevresi -Kaklık dolaylarındaki-traverten ocaklarında, blok üretiminde kullanılan zincirli kollu kesme makinelerinin kesme performanslarını incelemişlerdir [7]. Sarışık yaptığı çalışmada zincirli kollu kesme makinesinin başta traverten ocakları olmak üzere tüm doğal taş ocaklarında kullanımı ile birim zamanda daha az maliyetle daha fazla blok üretimi gerçekleştirildiğini gözlemlemiştir. Traverten ocaklarında elmas tel kesme yöntemi ile blok verimliliği \% 7-14 değerlerinde iken blok verimliliği Kollu Zincirli Kesme Makinesinin (DZK-3400) kullanımıyla \% 65-80 değerlerine yükseldiğini hesaplamıştır [8].

Çopur vd., yaptıkları çalışmada zincirli kollu kesme makinesini kullanan doğaltaş ocaklarını ziyaret ederek doğaltaş örnekleri almış ve zincirli kollu kesme makinesi ile ilgili kayıtlar tutarak bu makinenin performansı ve makinenin kullanım koşullarını araştırmışlardır. Örneklerin fiziksel özelliklerini tanımladıktan sonra keski tipi kesici araçlarını kullanarak doğrusal kesim testleri yapmışlardır. Taşların kesilebilirliklerini belirlemek için farklı yan açılara sahip keski araçları ile kesme performansı arasındaki ilişkileri ve mekanik özellikleri araştırmışlardır [9].

Yeşilkaya vd., yaptıkları çalışmada Isparta-Senirkent civarındaki bir kireçtaşı (bej mermer) ocağında, blok üretiminde elmas tel kesme ile kombine olarak kullanılan zincirli kollu kesme makinelerinin çalışma hızları, uygulama koșulları, malzeme gereksinimleri ve kesme performanslarını incelemişlerdir [10].

Önceki araștırmalarda, zincirli kollu kesicilerle blok kesiminde kesici kol basıncl, makine yürüyüş hızı ve zincir dönüş hızı gibi makine çalışma parametrelerinin kesim performansına etkisi incelenmemiştir. Ocakta işletmeciler tarafından uygulanan makine parametrelerinde kesim hızları ölçülmüştür. Bu tez çalışmasında bu parametrelerin kesim performansına etkisi 4 farklı doğaltaş ocağında gerçekleştirilen ölçümlerle incelenmiştir.

\section{Materyal ve Metot}

Bu çalışma kapsamında inceleme, gözlem ve ölçümler yapmak için Antalya-Burdur-Denizli civarındaki iki bej, bir limra ve bir traverten ocağına numune temini için de mermer işleme fabrikalarına gidilmiştir. Saha çalışmalarında öncelikle şirket ve ocak ile ilgili genel bilgiler, ocakta çalışma düzeni ile ilgili bilgiler, ocakta kullanılan zincirli kollu kesme makineleri ile ilgili bilgiler elde edilmeye çalışılmıştır. $\mathrm{Bu}$ bilgiler toplandıktan sonra zincirli kollu kesme makinesi performans ve ișletme parametreleri kayıtları tutulmuştur.

Makinelerin kullanım kılavuzları incelenerek ve teknik özellikleri araştırılarak makine üzerinde bulunan basınç göstergelerinden çalışılan basınç değerleri ve makine üzerinde bulunan zincir dönme hız göstergesinden zincir dönme hızı değerleri okunmuştur.

\section{1. Çalışma yapılan doğaltaş ocakları}

Tureks bej mermer ocağından 'Diana Royal' ve 'Cappuccino' adı verilen iki farklı seleksiyonda taş üretilmektedir. Ocağın görünür + muhtemel rezerv miktarı $80000000 \mathrm{~m}^{3}$ 'tür. 250 hektarlık alanın yaklaşık \%75'i kireçtaşından oluşmaktadır. \%25'lik kısımdan ise yan kayaç olarak alüvyonlar ve killi ofiyolitler çıkmaktadır. Ocakta çatlak sistemleri doğubatı yönlerinde yer almaktadır. Çatlak eğimleri \%70$\% 90$ arasındadır. Ocakta su geliri yoktur. Ocakta yılda ortalama $25000 \mathrm{~m}^{3}$ blok üretimi yapılmaktadır. Ortalama blok boyutları $4 \mathrm{~m}^{3}-8 \mathrm{~m}^{3}$ arasında olmaktadır. Fabrika blok işleme kapasitesi ise 60000 $\mathrm{m}^{3} / \mathrm{yll}$ 'dır.

Tureks bej mermer ocağında blok üretiminde önce 10 cm çapında yatay sondaj delikleri delinerek 45-55 kw gücündeki elmas boncuklu tel kesme makineleri ile alt kesim yapılmaktadır. Daha sonra kademe üzerinde kademe boyunca değișen uzunluklarda Fantini 70 SUPER-H zincirli kollu kesici ile düşey kesim yapılmaktadır. Ocakta kesme yüksekliği yaklaşık 3,5 metredir. Kesme uzunluğu 20-40 metre arasındadir.

Adalya bej mermer ocağından 'Adonis' olarak adlandırılan taş üretilmektedir. Ocağın görünür rezerv miktarı $600000 \mathrm{~m}^{3}$ tür. 150 hektarlık alanın yaklaşık \%90'ı kireçtaşından oluşmaktadır. \%10'luk kısımdan ise yüzeye yakın kısımlarda kil çıkmaktadır. Ocakta çatlak sistemleri doğu-batı yönlerinde yer almaktadır. Çatlak eğimleri \%70 - \%90 arasındadır. Ocakta su geliri yoktur. Ocakta yılda ortalama 15000 ton blok üretimi yapılmaktadır. Ortalama blok boyutları $200 \mathrm{~cm} \mathrm{x} 150 \mathrm{~cm}$ x $100 \mathrm{~cm}$ olmak üzere 2 $\mathrm{m}^{3}-3 \mathrm{~m}^{3}$ arasında olmaktadır. Fabrika blok işleme kapasitesi ise 7800 ton/yıl'dır.

Adalya bej mermer ocağında blok üretiminde önce 10 cm çapında yatay sondaj delikleri delinerek 45-55 kw gücündeki elmas boncuklu tel kesme makineleri ile alt kesim yapılmaktadır. Daha sonra kademe üzerinde kademe boyunca değişen uzunluklarda Fantini 70 SUPER-H zincirli kollu kesme makinesi ile düşey kesim yapılmaktadır. Kesme yüksekliği yaklaşık 7,2 metredir. Kesme uzunluğu 10-20 metre arasindadir. 
Tablo 1. Ocaklarda kullanılan zincirli kollu kesme makinelerinin teknik özellikleri

\begin{tabular}{|c|c|c|c|c|}
\hline & $\begin{array}{l}\text { Tureks diana-royal } \\
\text { bej }\end{array}$ & Adalya adonis bej & Demmer traverten & $\begin{array}{c}\text { Natüralmar } \\
\text { limra }\end{array}$ \\
\hline Üretici Firma & FANTİII & FANTINİ & DEMMAK & GARRONE \\
\hline Model & 70 SUPER-H & 70 SUPER-H & DZK 3400 & MCRH 740 \\
\hline Üretim Yılı & 2012 & 2014 & 2013 & 2007 \\
\hline Ağırlık & $10.000 \mathrm{~kg}$ & $10.000 \mathrm{~kg}$ & $9.000 \mathrm{~kg}$ & $10.000 \mathrm{~kg}$ \\
\hline Boyutlar & $4160 \times 2150 \times 2380 \mathrm{~mm}$ & $4160 \times 2150 \times 2380 \mathrm{~mm}$ & $4160 \times 2150 \times 2380 \mathrm{~mm}$ & - \\
\hline Toplam Kurulu Güç & $63,87 \mathrm{kw}$ & $63,87 \mathrm{kw}$ & $45,97 \mathrm{kw}$ & $63 \mathrm{kw}$ \\
\hline $\begin{array}{l}\text { Maksimum Kol } \\
\text { Uzunluğu }\end{array}$ & 4,90 metre & 8,70 metre & 4,30 metre & 5,40 metre \\
\hline Kol Dönüş Açışı & $360^{\circ}$ & $360^{\circ}$ & $360^{\circ}$ & $360^{\circ}$ \\
\hline $\begin{array}{l}\text { Maksimum Zincir } \\
\mathrm{Hızl}\end{array}$ & $0,7 \mathrm{~m} / \mathrm{sn}$ & $0,7 \mathrm{~m} / \mathrm{sn}$ & $1,5 \mathrm{~m} / \mathrm{sn}$ & $1,8 \mathrm{~m} / \mathrm{sn}$ \\
\hline $\begin{array}{l}\text { Maksimum Araba } \\
\text { Hızı }\end{array}$ & $15 \mathrm{~cm} / \mathrm{dak}$ & $15 \mathrm{~cm} / \mathrm{dak}$ & $18 \mathrm{~cm} / \mathrm{dak}$ & $20 \mathrm{~cm} / \mathrm{dak}$ \\
\hline Kesim Kalınlığı & $40 \mathrm{~mm}$ & $38 \mathrm{~mm}$ & $40 \mathrm{~mm}$ & $42 \mathrm{~mm}$ \\
\hline
\end{tabular}

Demmer Denizli-kaklık traverten ocağından yumuşak ve orta sert şeklinde olmak üzere iki farklı traverten üretilmektedir. Yumuşak travertenin yoğunluğu 2,15 $\mathrm{g} / \mathrm{cm}^{3}$ iken orta sert travertenin yoğunluğu 2,20 $\mathrm{g} / \mathrm{cm}^{3}$ 'tür. Ocağın görünür + muhtemel rezerv miktarı $100000000 \mathrm{~m}^{3}$ 'tür. Oluşum tamamen kireçtaşıdır. Yüzeyden 30 metre tabana doğru pasa mevcuttur. Yer yer bazı kısımlarda fosiller çıkmaktadır. Ocağın bazı yerlerinde kırılmalar görülmektedir ve faylardan dolayı oluşan kırılmalar yüzeyden tabana doğru gitmektedir. Ayrıca ocağın bazı yerlerinde görülen faylarda yeșil renkte ince şeritler görülmektedir. Ocakta su geliri olmamaktadır. Ocakta yılda ortalama $50000 \mathrm{~m}^{3}$ blok üretimi yapılmaktadır. Ortalama blok boyutları 3,5 $\mathrm{m}^{3}-4 \mathrm{~m}^{3}$ arasında olmaktadır. Fabrika blok işleme kapasitesi yalnızca denizli traverteni için $10000 \mathrm{~m}^{3} /$ yıl'dır. Demmer Denizli-kaklık traverten ocağında blok üretiminde önce kademe boyunca Demmak DZK 3400 zincirli kollu kesme makinesi ile düşey kesim yapılmaktadır.

Zincirli kollu kesme makinesi kademe üzerinde ilerledikçe kademe altından $10 \mathrm{~cm}$ çapında yatay sondaj delikleri delinerek 20 - 25 kw gücündeki elmas boncuklu tel kesme makineleri ile düşey kesimler yapılmaktadır. Kesme yüksekliği yaklaşık 3,8 metredir. Kesme uzunluğu 80-90 metre arasındadır. Zincirli kollu kesme makinesinin kol uzunluğu dişli dâhil 4,30 metredir.

Natürelmar limra ocağından 'Anatolion Aritto', 'Myra' ve 'Parla Bianca' olarak adlandırılan 3 farklı seleksiyonda taş üretilmektedir. Ocağın görünür rezerv miktarı 5000000 ton'dur. Ocakta üretilen taş kireçtaşı oluşumudur. Yapı sadece ana kayadır yani limradır ancak yüzeye yakın kesimlerde fosilli dolomitik yapı görülmektedir. Ocakta çatlak sistemleri kademelere dik ve güneydoğu-kuzeybatı istikametindedirler. Ocakta su geliri yoktur. Ocakta yılda ortalama yaklaşık 100000 ton blok üretimi yapılmaktadır. Ocak verimi yaklaşık olarak \% 60'dır.
Ortalama blok boyutları $200 \mathrm{~cm}$ x $160 \mathrm{~cm}$ x $150 \mathrm{~cm}$ olmak üzere $4 \mathrm{~m}^{3}-5 \mathrm{~m}^{3}$ arasında olmaktadır. Fabrika blok işleme kapasitesi ise yılda 48000 ton'dur.

Natürelmar limra ocağında alt kesimler Garrone MCRH 740 zincirli kollu kesici ile yatay olarak yapılmaktadır. Kesme genişliği yaklaşı 3,30 metredir. Kesme uzunluğu 20-40 metre arasındadır. Ocaklarda kullanılan zincirli kollu kesme makinelerinin teknik özellikleri Tablo 1'de verilmiştir.

Doğaltaș ocaklarında kullanılan zincirli kollu kesme makinesi keski grubundaki keski dizilimleri Şekil 2, Şekil 3, Şekil 4 ve Şekil 5'de verilmiştir.

PCD PCD PCD PCD PCD PCD PCD PCD PCD PCD PCD PCD PCD PCD PCD PCD

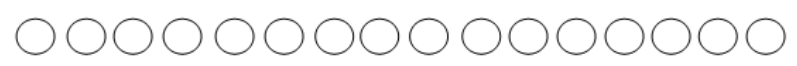

$\begin{array}{llllllllllllllll}\text { A } & \text { B } & 1 & 2 & 3 & 4 & 5 & 6 & 7 & 8 & 9 & 10 & 11 & 12 & 13 & 14\end{array}$

Şekil 2. Tureks bej mermer ocağında kullanılan Fantini 70 SUPER-H zincirli kollu kesme makinesi keski grubundaki pcd keskilerin dizilimi

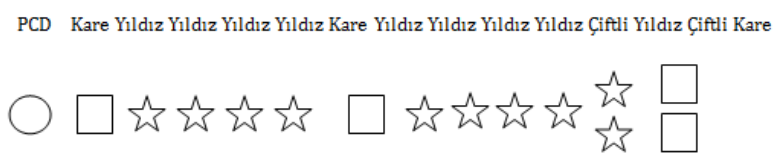

CMFo CMFo F2 F3 F3A F3B CMFo F4 F5 6DF F6S F6A CMF6

Şekil 3. Adalya bej mermer ocağında kullanılan Fantini 70 SUPER-H zincirli kesme makinesinde keski grubundaki pcd,kare ve yıldız keskilerin dizilimi

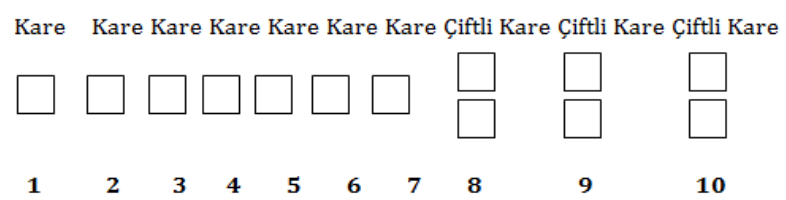

Şekil 4. Traverten mermer ocağında kullanılan Demmak DZK 3400 zincirli kollu kesme makinesi keski grubundaki kare keskilerin dizilimi 
Kare Kare Kare Kare Kare Kare Kare Kare Kare CCiftli Kare

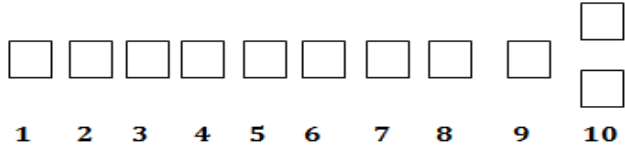

Şekil 5. Natürelmar limra mermer ocağında kullanılan Garrone MCRH 740 zincirli kollu kesme makinesi keski grubundaki kare keskilerin dizilimi

Doğaltaş ocaklarında kullanılan zincirli kollu kesme makinelerindeki kesme düzenleri Șekil 6, Șekil 7, Şekil 8 ve Şekil 9' da verilmiştir.

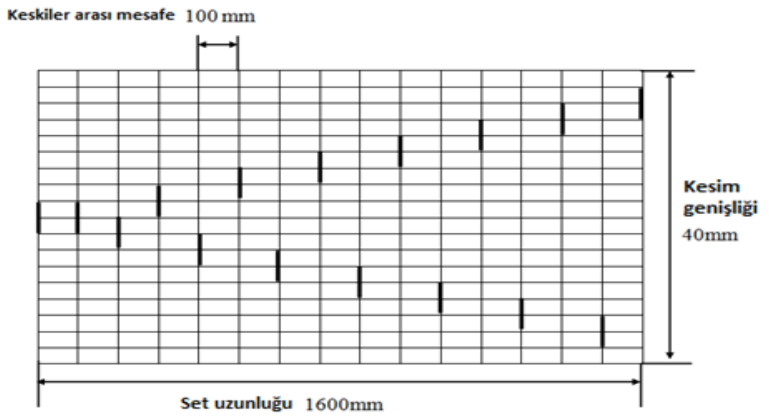

Şekil 6. Tureks bej Fantini 70 SUPER-H zincirli kesme makinesinde kesme düzeni

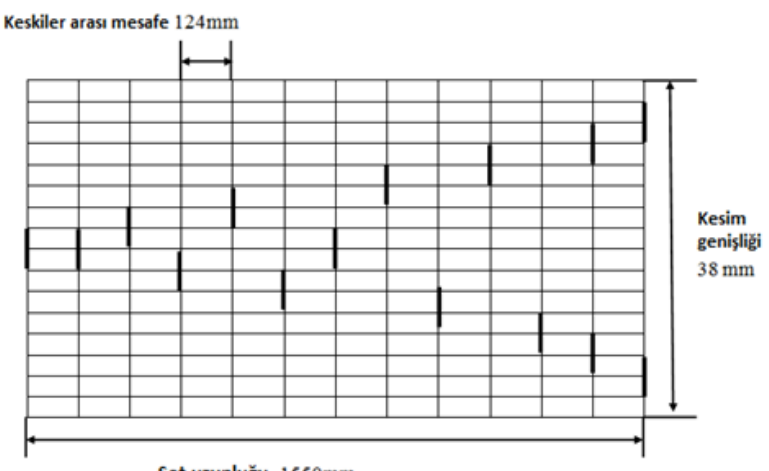

Şekil 7. Adalya bej Fantini 70 SUPER-H zincirli kesme makinesinde kesme düzeni

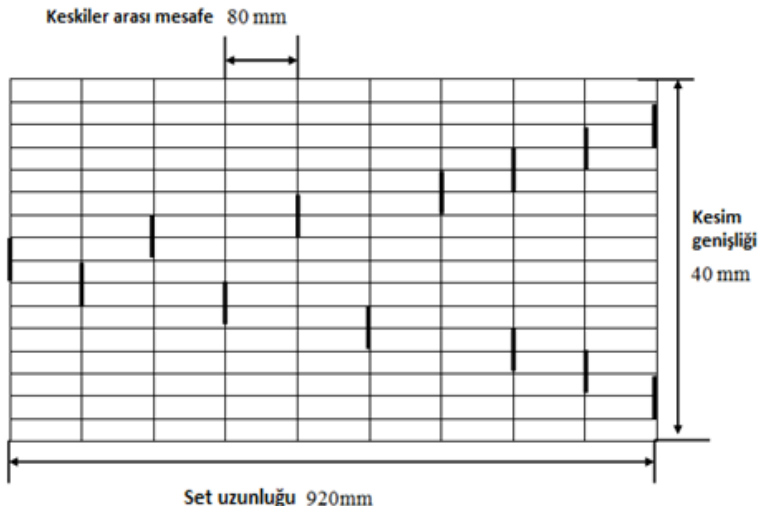

Sekil 8. Traverten Demmak DZK 3400 zincirli kesme makinesinde kesme düzeni

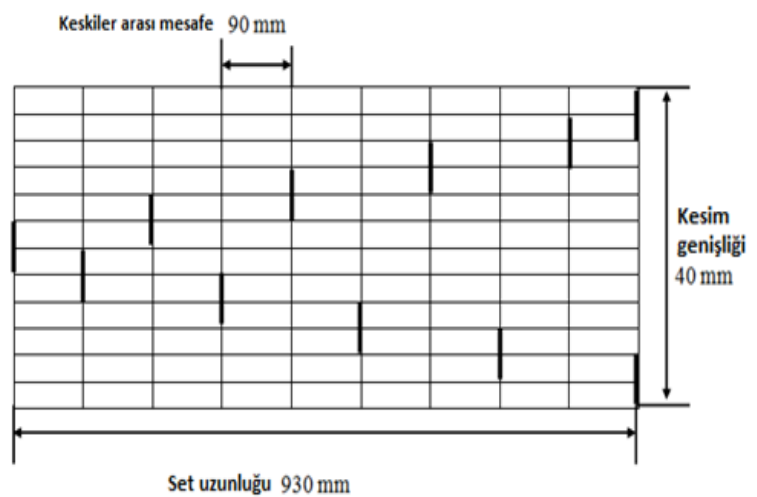

Şekil 9. Limra mermer ocağında Garrone MCRH 740 zincirli kollu kesme makinesinde kesme düzeni

\section{Bulgular}

Çalışma yapılan doğaltaş ocaklarının fabrikalarından alınan numunelerin Süleyman Demirel Üniversitesi doğaltaşlar laboratuarında yapılan deneylerle fizikomekanik özellikleri belirlenmiştir. Doğaltaşların fiziksel ve mekanik özellikleri Tablo 2'de verilmektedir.

Tablo 2. Doğaltașların fiziksel ve mekanik özellikleri

\begin{tabular}{|c|c|c|c|c|c|c|}
\hline \multicolumn{2}{|c|}{ Doğal Taşlar } & $\begin{array}{c}\text { Birim hacim } \\
\text { ağırlık } \\
\left(\mathrm{g} / \mathrm{cm}^{3}\right)\end{array}$ & $\begin{array}{l}\text { Görünür } \\
\text { porozite } \\
(\%)\end{array}$ & $\begin{array}{l}\text { Schmidt } \\
\text { sertliği }\end{array}$ & $\begin{array}{l}\text { P-dalga hızı } \\
\text { (m/s) }\end{array}$ & $\begin{array}{c}\text { Tek eksenli } \\
\text { basınç dayanımı } \\
\text { (MPa) }\end{array}$ \\
\hline \multirow{2}{*}{$\begin{array}{c}\text { Cappuccino } \\
\text { Bej }\end{array}$} & $\begin{array}{c}\text { Ortalama } \\
\text { değer }\end{array}$ & 2,66 & 1,20 & 27,20 & 6178,55 & 99,83 \\
\hline & $\begin{array}{l}\text { Standart } \\
\text { Sapma }\end{array}$ & 0,02 & 0,52 & 1,10 & 199,74 & 19,21 \\
\hline \multirow{2}{*}{$\begin{array}{l}\text { Adonis } \\
\text { Bej }\end{array}$} & $\begin{array}{c}\text { Ortalama } \\
\text { değer }\end{array}$ & 2,70 & 0,26 & 38,80 & 6379,47 & 143,99 \\
\hline & $\begin{array}{l}\text { Standart } \\
\text { Sapma }\end{array}$ & 0,01 & 0,06 & 1,10 & 123,26 & 12,18 \\
\hline \multirow{2}{*}{ Limra } & $\begin{array}{l}\text { Ortalama } \\
\text { değer }\end{array}$ & 2,35 & 5,61 & 23,20 & 4214,80 & 50,78 \\
\hline & $\begin{array}{l}\text { Standart } \\
\text { Sapma }\end{array}$ & 0,01 & 0,38 & 1,10 & 41,32 & 7,77 \\
\hline \multirow{2}{*}{ Traverten } & $\begin{array}{l}\text { Ortalama } \\
\text { değer }\end{array}$ & 2,23 & 5,73 & 18,00 & 3096,91 & 19,93 \\
\hline & $\begin{array}{l}\text { Standart } \\
\text { Sapma }\end{array}$ & 0,10 & 1,13 & 1,41 & 254,86 & 9,46 \\
\hline
\end{tabular}


Tablo 3. Tureks diana royal-cappuccino bej ocağında kesimde yapılan performans ölçüm sonuçlarının özeti

\begin{tabular}{|c|c|c|c|c|c|c|}
\hline $\begin{array}{c}\text { Ayarlanan } \\
\text { zincir dönüş } \\
\text { hızı } \\
(\mathrm{m} / \mathrm{sn})\end{array}$ & $\begin{array}{l}\text { Ayarlanan } \\
\text { makine } \\
\text { yürüyüș hızı } \\
(\mathrm{cm} / \mathrm{dk})\end{array}$ & $\begin{array}{l}\text { Zincir } \\
\text { dönüş } \\
\text { basincl } \\
\text { (bar) }\end{array}$ & $\begin{array}{l}\text { Makine } \\
\text { yürüyüş } \\
\text { basıncl } \\
\text { (bar) }\end{array}$ & $\begin{array}{l}\text { Kesim hizı } \\
\left(\mathrm{m}^{2} / \mathrm{h}\right)\end{array}$ & $\begin{array}{l}\text { Keski seti } \\
\text { kesme } \\
\text { derinliği } \\
(\mathrm{mm})\end{array}$ & $\begin{array}{c}\text { Pasa } \\
\text { irilik } \\
\text { indeksi }\end{array}$ \\
\hline 0,49 & 3 & 93 & 46 & 4,68 & 1,17 & 376 \\
\hline 0,52 & 3 & 95 & 47 & 4,89 & 1,15 & - \\
\hline 0,55 & 3 & 100 & 48 & 5,31 & 1,18 & 364 \\
\hline 0,58 & 3 & 112 & 49 & 5,1 & 1,08 & - \\
\hline 0,62 & 3 & 115 & 49 & 4,68 & 0,93 & 360 \\
\hline 0,58 & 1,5 & 82 & 26 & 3,7 & 0,78 & 368 \\
\hline 0,58 & 2,25 & 84 & 27 & 3,95 & 0,83 & - \\
\hline 0,58 & 3 & 88 & 42 & 5,1 & 1,08 & 372 \\
\hline 0,58 & 3,75 & 115 & 51 & 6,78 & 1,43 & - \\
\hline 0,58 & 4,5 & 130 & 60 & 6,15 & 1,30 & 377 \\
\hline
\end{tabular}

Tureks bej ocağında kesimde yapılan performans ölçüm sonuçlarının özeti Tablo 3'de verilmiştir. Kesimde kol kesme derinliği 3,5 m, kol kesme açısı $75^{\circ}$, keski seti uzunluğu 1,6 m'de makine yürüyüş hızı $3 \mathrm{~cm} / \mathrm{dk}^{\prime}$ da sabit iken zincir dönüş hızı 0,55 m/sn değerine artırıldığında zincir dönüş basıncında ve kesim hızında az bir artış olmaktadır. Zincir hızı 0,55 $\mathrm{m} / \mathrm{sn}$ 'den yüksek bir değere ayarlandığında zincir basıncı hala artmakta, makine kesimde zorlanmakta ve kesim hızında azalma olmaktadır (Şekil 10). Zincir hızı 0,55 m/sn değerine kadar keski kesme derinliğinde önemli bir değişiklik olmamış daha büyük zincir hızı değerlerinde kesme derinliği azalmıştır (Şekil11). Zincir hızı artışıyla pasa irilik indeksinin azaldığı kesimden daha küçük boyutta pasa çıktığı gözlemlenmiştir (Tablo3).

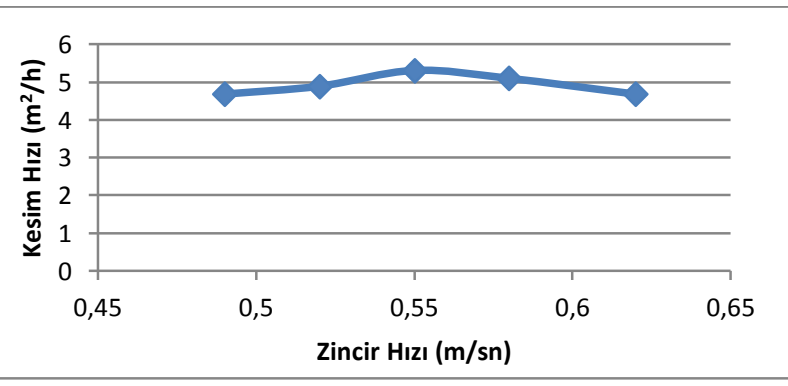

Şekil 10. Tureks bej mermer ocağında ana kesimde zincir hızının kesim hızına etkisi

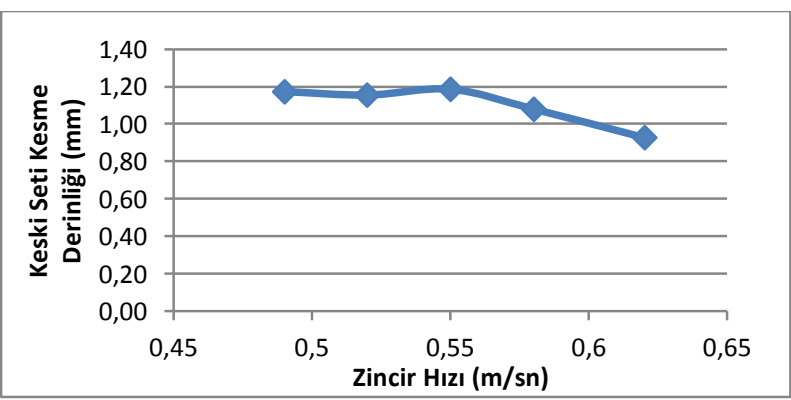

Şekil 11. Tureks bej mermer ocağında ana kesimde zincir hızının keski seti kesme derinliğine etkisi

Tureks bej mermer ocağında kesimde yapılan performans ölçüm sonuçlarına göre zincir hızı 0,58 m/sn'de sabit tutulup makine yürüyüş hızı artırıldığında kesim esnasında hem zincir dönüş basıncı, hem de makine yürüyüş basıncı artmaktadır. Makine yürüyüş hızının artırılmasıyla kesim hızı ve keski kesme derinliği artmakta, 3,75 cm/dk değerinden sonra kesim performansı düşmektedir (Şekil 12 ve Şekil 13). Ancak makine yürüyüş hızı 3,75 ve $4,5 \mathrm{~cm} / \mathrm{dk}$ değerlerine artırıldığında zincir dönüş basıncı sırasıyla 115 ve 130 bar, makine yürüyüş basıncl ise 51 ve 60 bar seviyelerine yükselmiştir. $\mathrm{Bu}$ değerlerde makine zorlanmaya başlamıştır. 4,5 cm/dk yürüme hızı değerinde makinenin uyarı lambası yanmış, bu değerde sadece 2 dakika süre tutulabilmiştir. Aksi halde makine kendini korumaya alıp çalışmayı durduracaktır. Makine yürüyüş hızının artmasıyla beraber pasa irilik indeksinin arttığı yani kesimden çıkan pasanın da daha büyük boyutlarda olduğu gözlemlenmiștir (Tablo 3).

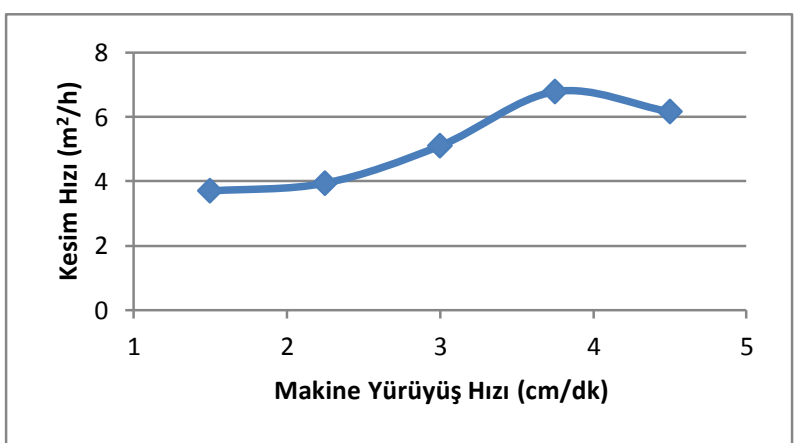

Şekil 12. Tureks bej mermer ocağında ana kesimde makine yürüyüş hızının kesim hızına etkisi

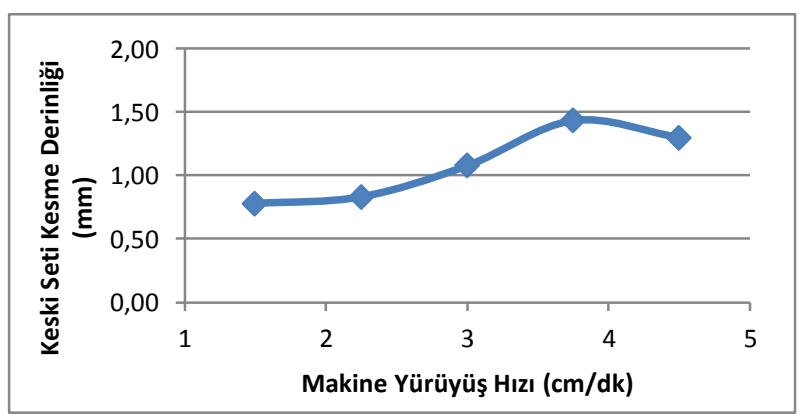

Şekil 13. Tureks bej mermer ocağında ana kesimde makine yürüyüş hızının keski seti kesme derinliğine etkisi 
Tablo 4. Adalya bej mermer ocağında kesimde yapılan performans ölçüm sonuçlarının özeti

\begin{tabular}{ccccccc}
\hline $\begin{array}{c}\text { Ayarlanan } \\
\text { zincir dönüş } \\
\text { hızl } \\
\text { (m/sn) }\end{array}$ & $\begin{array}{c}\text { Ayarlanan } \\
\text { makine } \\
\text { yürüyüș hızl } \\
\text { (cm/dk) }\end{array}$ & $\begin{array}{c}\text { Zincir } \\
\text { dönüş } \\
\text { basincl } \\
\text { (bar) }\end{array}$ & $\begin{array}{c}\text { Makine } \\
\text { yürüyüş } \\
\text { basıncl } \\
\text { (bar) }\end{array}$ & $\begin{array}{c}\text { Kesim hızı } \\
\left(\mathrm{m}^{2} / \mathrm{h}\right)\end{array}$ & $\begin{array}{c}\text { Keski seti } \\
\text { kesme } \\
\text { derinliği } \\
\text { (mm) }\end{array}$ & $\begin{array}{c}\text { Pasa } \\
\text { irilik } \\
\text { indeksi }\end{array}$ \\
\hline 0,35 & 3,75 & 120 & 31 & 8,89 & 1,47 & 437 \\
0,39 & 3,75 & 115 & 30 & 8,90 & 1,32 & - \\
0,42 & 3,75 & 110 & 30 & 8,92 & 1,23 & 429 \\
0,45 & 3,75 & 108 & 29 & 8,93 & 1,15 & - \\
0,49 & 3,75 & 103 & 29 & 8,95 & 1,06 & 422 \\
0,42 & 2,25 & 80 & 10 & 3,73 & 0,51 & 413 \\
0,42 & 3 & 90 & 22 & 4,59 & 0,63 & - \\
0,42 & 3,75 & 110 & 29 & 8,52 & 1,17 & 420 \\
0,42 & 4,5 & 130 & 30 & 9,10 & 1,25 & - \\
0,42 & 5,25 & 150 & 35 & 10,42 & & 1,43 \\
\hline
\end{tabular}

Ocakta operatör tarafindan kesimde alınan ortalama kesim miktarları 2,80 $\mathrm{m}^{2} / \mathrm{h}$ ile $4,30 \mathrm{~m}^{2} / \mathrm{h}$ arasındadır. Ana kesimde zincir dönüş hızı 0,50 m/sn ile 0,55 $\mathrm{m} / \mathrm{sn}$ arasında, makine yürüyüş hızı ise $3,0 \mathrm{~cm} / \mathrm{dk}$ ile $3,5 \mathrm{~cm} / \mathrm{dk}$ arasında alınırsa yaklaşık olarak $5 \mathrm{~m}^{2} / \mathrm{h}$ ile $5,5 \mathrm{~m}^{2} / \mathrm{h}$ arasında üretim gerçekleșecektir. Sonuç olarak bu değerlerde üretim miktarı artışı olacağı görülmektedir.

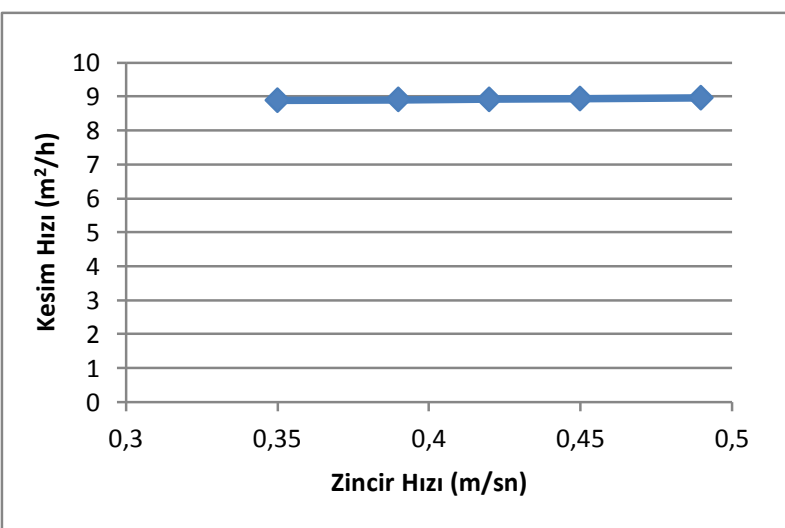

Şekil 14. Adonis bej ocağında ana kesimde zincir hızının kesim hızına etkisi

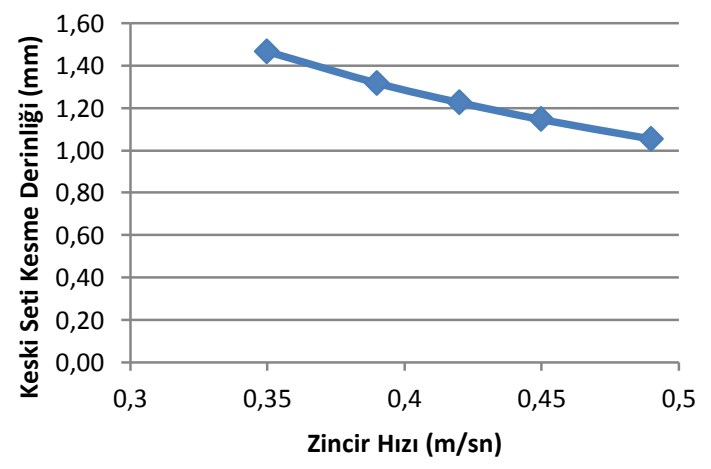

Şekil 15. Adonis bej ocağında ana kesimde zincir hızının keski seti kesme derinliğine etkisi

Adalya bej mermer ocağında kesimde yapılan performans ölçüm sonuçlarının özeti Tablo 4'de verilmiştir. Adalya adonis bej mermer ocağında ana kesimde kol kesme derinliği 7,2 m, kol kesme açısı $75^{\circ}$, keski seti uzunluğu 1,55 m'de makine yürüyüş hızı 3,75 cm/dk değerinde sabit tutulup zincir dönüş hızı artırıldığında, zincir dönüş basıncı ve makine yürüyüş basıncı kısmen azalmakta kesim hızı ise az bir miktarda olsa artmaktadır (Şekil 14). Aynı makine yürüyüș hızında zincir hızının artması keski kesme derinliğinin azalmasına neden olmaktadır (Şekil 15). Zincir hızı artışıyla pasa irilik indeksinin azaldığı kesimden daha küçük boyutta pasa çıktı̆̆ gözlemlenmiştir (Tablo 4).

Adalya bej mermer ocağında kesimde yapılan performans ölçüm sonuçlarına göre zincir hızı 0,42 m/sn'de sabit tutulup makine yürüyüş hızı artırıldığında kesim esnasında hem zincir dönüş basıncı hem de makine yürüyüş basıncı artmaktadır. Makine yürüyüş hızının artırılmasıyla kesim hızı ve keski kesme derinliği artmaktadır (Şekil 16 ve Şekil 17). Ancak makine $3,75 \mathrm{~cm} / \mathrm{dk}^{\prime}$ dan daha büyük değere artırıldığında hem kesme derinliği hem de kesim hızında stabil bir artıș olmamaktadır. Makine yürüyüş hızı 4,5 cm/dk değerine artırıldığında zincir dönüş basıncl 130 bar seviyesine yükselmiş ve makinenin kırmızı uyarı lambası yanmıştır. $\mathrm{Bu}$ değerde devam edilmesi halinde makine kendini korumaya alıp çalışmayı durduracaktır. Makine yürüyüş hızının artmasıyla beraber pasa irilik indeksinin arttığı ve kesimden çıkan pasanın da daha büyük boyutlarda olduğu gözlemlenmiștir (Tablo 4).

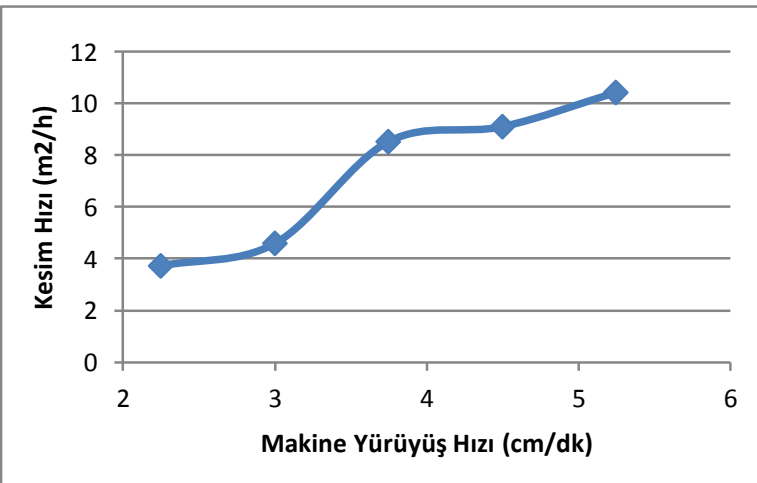

Şekil 16. Adonis bej ocağında ana kesimde makine yürüyüşü hızının kesim hızına etkisi 


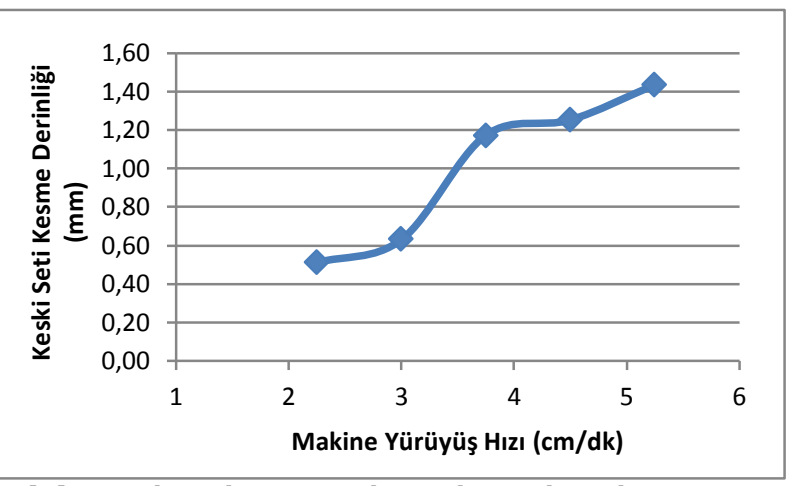

Şekil 17. Adonis bej ocağında ana kesimde makine yürüyüş hızının keski seti kesme derinliğine etkisi

Ocakta operatör tarafindan kesimde alınan ortalama kesim miktarı $7 \mathrm{~m}^{2} / \mathrm{h}$ ile $8 \mathrm{~m}^{2} / \mathrm{h}$ arasındadır. Kesimde zincir dönüş hızı $0,42 \mathrm{~m} / \mathrm{sn}$ ile $0,49 \mathrm{~m} / \mathrm{sn}$ arasında ve makine yürüyüş hızı ise $3,5 \mathrm{~cm} / \mathrm{dk}$ ile 4 $\mathrm{cm} / \mathrm{dk}$ arasında alınırsa yaklaşık olarak $8,5 \mathrm{~m}^{2} / \mathrm{h}$ ile 9 $\mathrm{m}^{2} / \mathrm{h}$ üretim gerçekleşecektir. Sonuç olarak bu değerlerde üretim miktarı artışı olacağı görülmektedir.

Demmer Denizli-Kaklık traverten ocağında ana kesimde kol kesme derinliği 3,8 m, kol kesme açısı $80^{\circ}$ ve keski seti uzunluğu $0,92 \mathrm{~m}$ olup makine yürüyüş hızı ve zincir hızı değerleri kontrol düğmelerinden ayarlanmıştır. Kesim esnasında ampermetreden akım değerleri okunmuş ve bu değerler sürekli değiștiği içinde ortalamaları alınarak kaydedilmiştir.

Tablo 5'de kesim öncesi ayarlanan makine yürüyüş hızı ve zincir dönüş hızı değerlerinde; çalışma esnasında göstergelerden okunan akım, kol kesme açısı, kesme hızı ile kesimden çıkan pasanın irilik indeksi değerleri verilmektedir.

Denizli Traverten ocağında kesimde yaplan performans ölçüm sonuçlarına göre makine yürüyüş hızı 16,36 cm/dk'de sabit iken zincir hızı artırıldığında zincir daha rahat dönmüş ve kesim hızında önemli bir değișim olmamıștır (Șekil 18). Zincir hızı arttıkça keski kesme derinliği azaldığından (Şekil 19) makinenin çektiği akımda azalmıştır. Zincir dönüş hızının artmasıyla pasa irilik indeksinin azaldığı ve kesimden küçük boyutta malzeme elde edildiği görülmüştür (Tablo 5).

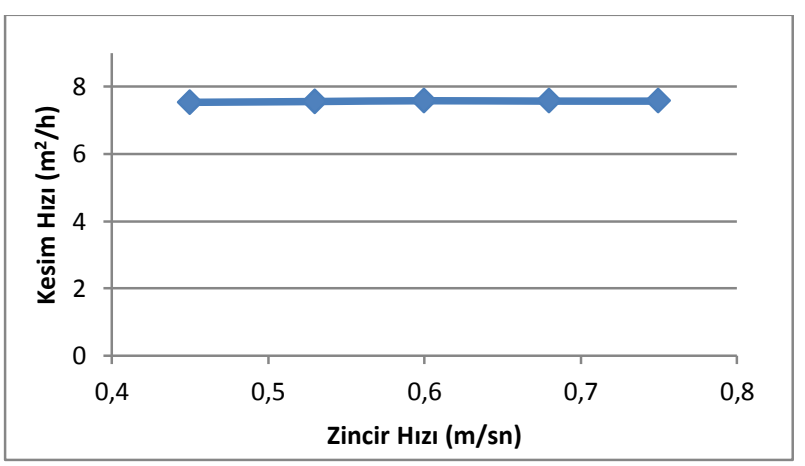

Şekil 18. Traverten ocağında ana kesimde zincir hızının kesim hızına etkisi

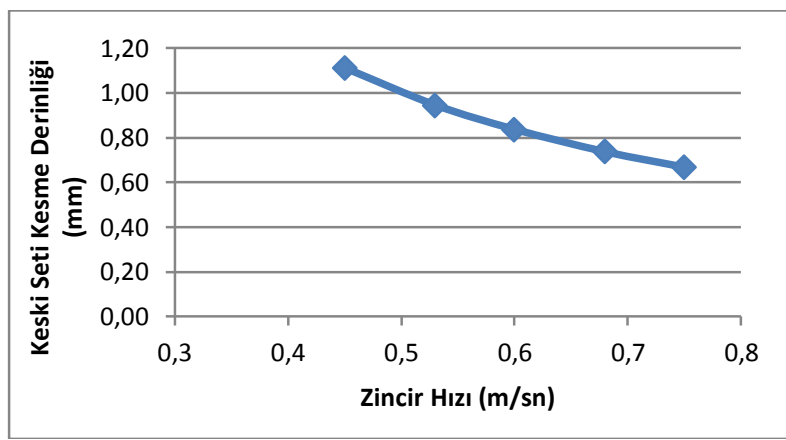

Şekil 19. Traverten ocağında ana kesimde zincir hızının keski seti kesme derinliğine etkisi

Kesimde zincir dönüş hızı 0,6 m/sn de sabit tutulup makine yürüyüş hızı artırıldığında makinenin çektiği akımda artmıştır. Traverten çok sağlam bir yapıda olmadığı için makinede zorlanma olmamıştır ve değerler anlık çok büyük bir fark olmadan değişiklik göstermiștir. Makine yürüyüș hızının artmasıyla kesim hızı az miktarda olsa artmıştır (Şekil 20). Makine yürüyüş hızının artmasıyla kesme derinliği de artmıştır (Şekil 21). Makine yürüyüş hızı arttıkça kesimden çıkan pasanın da irilik indeksinin arttığı yani daha büyük boyutlarda pasa çıtığı gözlemlenmiştir (Tablo 5).

Ocakta operatör tarafından kesimde alınan ortalama kesim miktarları $6,80 \mathrm{~m}^{2} / \mathrm{h}$ ile $7,10 \mathrm{~m}^{2} / \mathrm{h}$ arasında değişmektedir. Öngörülen çalışma parametrelerinde

Tablo 5. Denizli traverten ocağında kesimde yapılan performans ölçüm sonuçlarının özeti

\begin{tabular}{|c|c|c|c|c|c|}
\hline $\begin{array}{l}\text { Ayarlanan zincir } \\
\text { dönüş hızı } \\
(\mathrm{m} / \mathrm{sn})\end{array}$ & $\begin{array}{l}\text { Ayarlanan makine } \\
\text { yürüyüş hızı } \\
(\mathrm{cm} / \mathrm{dk})\end{array}$ & $\begin{array}{l}\text { Akım ölçümleri } \\
\text { (amper) }\end{array}$ & $\begin{array}{l}\text { Kesim hızı } \\
\left(\mathrm{m}^{2} / \mathrm{h}\right)\end{array}$ & $\begin{array}{c}\text { Keski seti kesme } \\
\text { derinliği } \\
(\mathrm{mm})\end{array}$ & $\begin{array}{l}\text { Pasa irilik } \\
\text { indeksi }\end{array}$ \\
\hline 0,45 & 16,36 & 28 & 7,55 & 1,11 & 440 \\
\hline 0,53 & 16,36 & 26 & 7,57 & 0,95 & - \\
\hline 0,6 & 16,36 & 24 & 7,59 & 0,84 & 434 \\
\hline 0,68 & 16,36 & 22 & 7,58 & 0,74 & - \\
\hline 0,75 & 16,36 & 21,5 & 7,58 & 0,67 & 406 \\
\hline 0,6 & 6,54 & 22 & 6,87 & 0,76 & 390 \\
\hline 0,6 & 8,18 & 23 & 6,91 & 0,76 & - \\
\hline 0,6 & 9,82 & 23,5 & 7,06 & 0,78 & 410 \\
\hline 0,6 & 11,45 & 24,3 & 7,18 & 0,79 & - \\
\hline 0,6 & 13,09 & 25,1 & 7,33 & 0,81 & 428 \\
\hline
\end{tabular}


kesim hızında önemli bir artışın sağlanamayacağı görülmektedir. Dolayısıyla mevcut çalışma koşulları uygun görünmektedir.

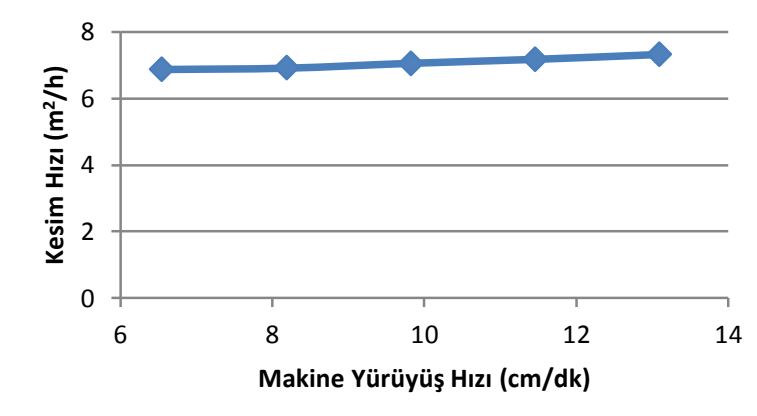

Şekil 20. Traverten ocağında ana kesimde makine yürüyüş hızının kesim hızına etkisi

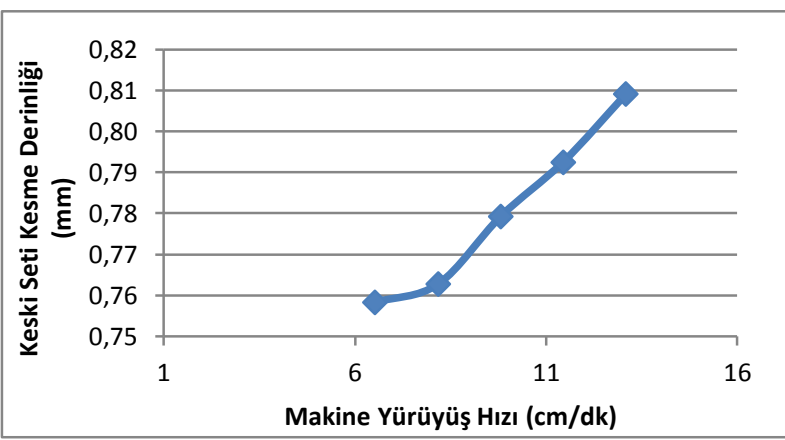

Şekil 21. Traverten ocağında ana kesimde makine yürüyüş hızının keski seti kesme derinliğine etkisi

Natürelmar limra ocağında ana kesimde kol kesme derinliği 3,30 m, kol kesme açısı $70^{\circ}$ ve keski seti uzunluğu 0,93 m olup makine yürüyüş hızı ve zincir hızı değerleri kontrol düğmelerinden ayarlanmıștır.

Tablo 6'da ana kesim öncesinde ayarlanan makine yürüyüş hızı ve zincir hızı değerlerinde; çalışma esnasında göstergelerden okunan makine yürüyüş basıncı ve zincir dönüş basıncı, kesme hızı ile kesimden çlkan pasanın irilik indeksi değerleri verilmektedir. Kesimde makine yürüyüş hızı 6 $\mathrm{cm} / \mathrm{dk}^{\prime}$ da sabit iken zincir dönüş hızı 0,9 m/sn ye kadar arttıkça zincir dönüş basıncı azalmakta, makine yürüyüş basıncında önemli bir değişiklik olmamaktadır. Zincir hızı kesim hızını çok fazla etkilememiş (Şekil 22), keski kesme derinliği ise önemli ölçüde azalmıştır (Şekil 23). Zincir hızı artışıyla birlikte pasa irilik indeksinin azaldığı kesimden daha küçük boyutta pasa çıtığ gözlemlenmiştir (Tablo 6).

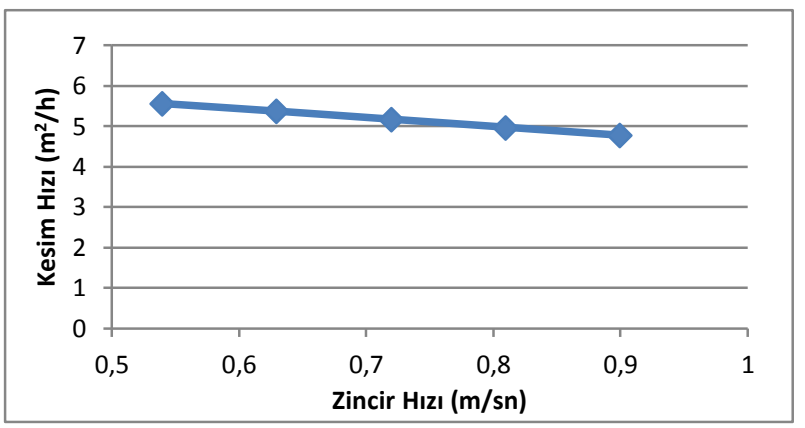

Şekil 22. Limra ocağında ana kesimde zincir hızının kesim hızına etkisi

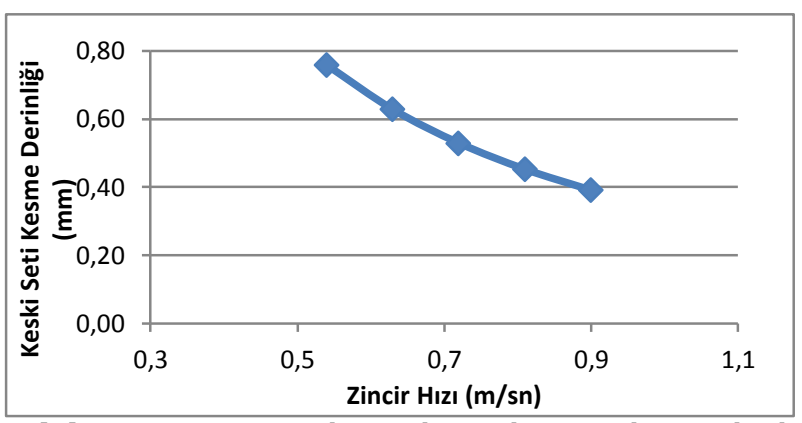

Şekil 23. Limra ocağında ana kesimde zincir hızının keski seti kesme derinliğine etkisi

Natürelmar Limra ocağında kesimde yapılan performans ölçüm sonuçlarına göre zincir hızı 0,9 $\mathrm{m} / \mathrm{sn}$ 'de sabit tutulup makine yürüyüş hızı artırıldıkça hem zincir dönüş basıncı hem de makine yürüyüş basıncı artmaktadır. Kesim hızında artış olmuş (Şekil 24), kesme derinliği de artmıştır (Şekil 25). Ancak yürüme hızı $10 \mathrm{~cm} / \mathrm{dk}^{\prime}$ dan fazla olduğunda kesim hızı ve kesme derinliğinde çok büyük artış olmamıştır. Yürüme hızı $14 \mathrm{~cm} / \mathrm{dk}^{\prime} \mathrm{da}$ basınç 120 bara gelmiş ve kol üzerine yükün aşırı bindiği ve kolun kastığı gözlemlenmiştir. Makine yürüyüş hızının artmasıyla beraber pasa irilik

Tablo 6. Natürelmar limra ocağında kesimde yapılan performans ölçüm sonuçlarının özeti

\begin{tabular}{ccccccc}
$\begin{array}{c}\text { Ayarlanan } \\
\text { zincir dönüş } \\
\text { hızı } \\
(\mathrm{m} / \mathrm{sn})\end{array}$ & $\begin{array}{c}\text { Ayarlanan } \\
\text { makine } \\
\text { yürüyüş hızı } \\
(\mathrm{cm} / \mathrm{dk})\end{array}$ & $\begin{array}{c}\text { Zincir } \\
\text { dönüş̧ } \\
\text { basıncl } \\
\text { (bar) }\end{array}$ & $\begin{array}{c}\text { Makine } \\
\text { yürüyüş̧ } \\
\text { basıncl } \\
\text { (bar) }\end{array}$ & $\begin{array}{c}\text { Kesim hızı } \\
\left(\mathrm{m}^{2} / \mathrm{h}\right)\end{array}$ & $\begin{array}{c}\text { Keski seti } \\
\text { kesme } \\
\text { derinliği } \\
(\mathrm{mm})\end{array}$ & $\begin{array}{c}\text { Pasa } \\
\text { irilik } \\
\text { indeksi }\end{array}$ \\
\hline 0,54 & 6 & 80 & 14 & 5,56 & 0,76 & 370 \\
0,63 & 6 & 78 & 15 & 5,37 & 0,63 & - \\
0,72 & 6 & 68 & 13 & 5,17 & 0,53 & 357 \\
0,81 & 6 & 60 & 15 & 4,97 & 0,45 & - \\
0,9 & 6 & 57 & 14 & 4,77 & 0,39 & 332 \\
0,9 & 6 & 42 & 80 & 4,37 & 0,36 & 328 \\
0,9 & 8 & 44 & 95 & 6,52 & 0,53 & - \\
0,9 & 10 & 45 & 100 & 7,38 & 0,60 & 401 \\
0,9 & 12 & 43 & 115 & 7,56 & 0,62 & - \\
0,9 & 14 & 47 & 120 & 7,98 & 0,65 & 413 \\
\hline
\end{tabular}


indeksinin arttığı ve kesimden çıkan pasanın da daha büyük boyutlarda olduğu gözlemlenmiștir (Tablo 6).

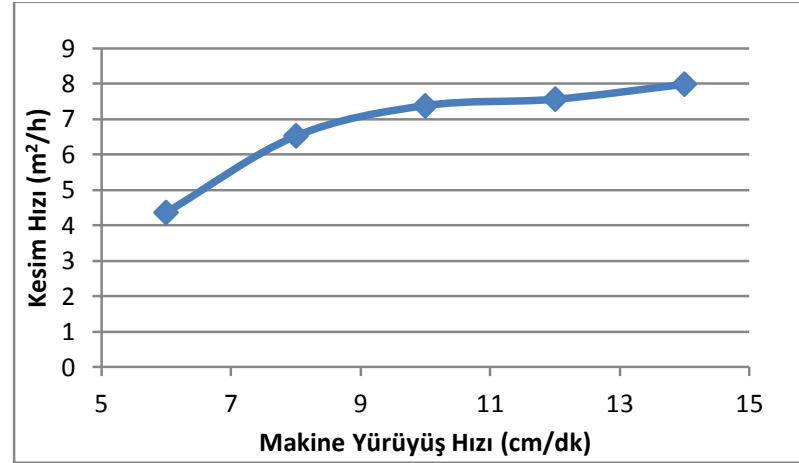

Şekil 24. Limra ocağında ana kesimde makine yürüyüş hızının kesim hızına etkisi

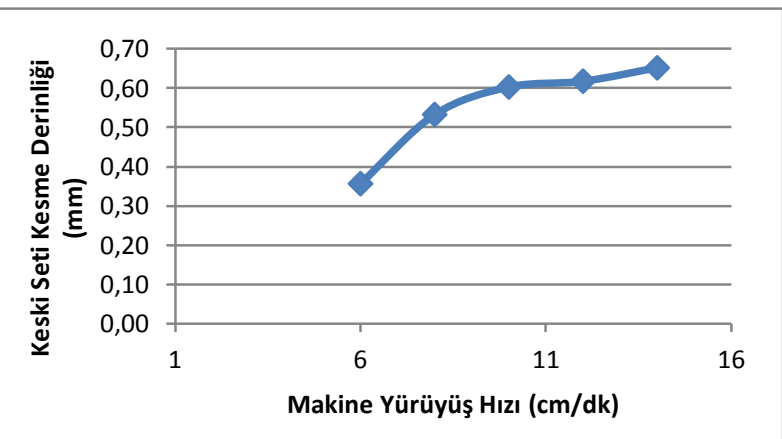

Şekil 25. Limra ocağında ana kesimde makine yürüyüş hızının keski seti kesme derinliğine etkisi

Ocakta operatör tarafından kesimde alınan ortalama kesim miktarları $6 \mathrm{~m}^{2} / \mathrm{h}$ ile $6,5 \mathrm{~m}^{2} / \mathrm{h}$ arasındadır. Kesimde zincir dönüş hızı $0,6 \mathrm{~m} / \mathrm{sn}$ ile $0,7 \mathrm{~m} / \mathrm{sn}$ arasında makine yürüyüş hızı ise $8 \mathrm{~cm} / \mathrm{dk}$ ile 10 $\mathrm{cm} / \mathrm{dk}$ arasında alınırsa yaklaşık olarak $6,5 \mathrm{~m}^{2} / \mathrm{h}$ ile 7 $\mathrm{m}^{2} / \mathrm{h}$ arasında üretim gerçekleşecektir. Sonuç olarak bu değerlerde üretim miktarı artışı olacağı görülmektedir.

\section{Tartışma ve Sonuç}

Zincirli kollu kesici makinenin ana kesim esnasinda zincir hızının artırılmasıyla keski seti kesme derinliği azaldığından pasa irilik indeksi de azalmakta yani kesimden daha küçük boyutta kırıntı çıkmaktadır. Sabit makine yürüyüş hızında zincir hızı arttıkça makinenin daha rahat kestiği görülmüștür. Ancak daha öncede belirtildiği gibi kesme derinliği düşük ise pasa irilik indeksi azalacak yani pasanın parça boyutu incelecek ve bunların sonucunda spesifik enerji artacaktır. Genel olarak zincir hızındaki değişimin kesme hızına çok fazla bir etkisinin olmadığı sadece kesimin zorluğunu etkilediği görülmüştür.

Ocaklarda zincirli kollu kesici ile yapılan kesme deneyleri sonucunda makinede ölçülen basınç değerleri ile makinenin zorlanma durumu (titreşim vb) gibi makine ile ilgili parametreler, kesme derinliği, kesme hızı ve çıkan pasanın boyutu gibi parametreler dikkate alınarak optimum çalışma koşulları belirlenmeye çalışılmış ve öneriler getirilmiştir. $\mathrm{Bu}$ önerilen değerler ana kesimler de uygulanarak kesimler tamamlanmıştır.

$\mathrm{Bu}$ çalışma ve araștırmalar sonucunda, zincirli kollu kesme makinelerinin çeşitli sebeplerden dolayı optimum kesme koşullarında çalışmadığı anlaşılmaktadır. Optimum koşullarda çalışabilecek bu makinelerin ocaklarda bu belirlenen parametrelerde çalıştırarak kesim yapılmasında kesim veriminin artışına ve hatta genel ocak veriminin de artışına katkı sağlayacağı ortadadır. Ayrıca bu belirlenen optimum değerlerde kesim yapılmasında makinenin aşırı zorlanmadan kesim yapmasından makine ömrüne de olumlu katkı sağlayacağı unutulmamalıdır.

\section{Kaynakça}

[1] Çalışkan, M. A., 2018. Mermer Ocaklarında Kullanilan Zincirli Kesme Makinelerinin Performanslarının Belirlenmesi. Süleyman Demirel Üniversitesi, Fen Bilimleri Enstitüsü, Yüksek Lisans Tezi, 119s, Isparta.

[2] Fantini, 2017. Erişim Tarihi: 29.12.2017. http://www.fantinispa.it/tr

[3] Önenç, D., Demirocak, Y., 2003. Tabaka Duruşlarına Göre Blok Kesim Yöntemlerinin Ocak Mermer İşletmeciliğinde Planlanması Ve Ayna Pozisyonlarının Dizaynları. Türkiye IV. Mermer Sempozyumu Bildiriler Kitabı. 18-19 Aralık, Afyon, 277-289.

[4] Çopur, H., Balcl, C., Bilgin, N., Tumac, D., Feridunoğlu, C., Dincer, T., 2006. Cutting Performance Of Chain Saws In Quarries And Laboratory. Proceeding of the 15th International Symposium on Mine Planning and Equipment Selection. Torino, Italy, 1-6.

[5] Demirel, Ş., 2008. Mermer Ocaklarında Kollu Zincirli Kesme Makinesinin Uygulanabilirliği. I. Ulusal Mermer ve Doğaltaşlar Kongresi, 1-2 Şubat, İzmir, 187-196.

[6] Çopur, H., Bilgin, N., Balcl, C., Tumaç, D., 2008. Doğal Taş Madenciliğinde Kullanılan Zincirli Kesme Makinelerinin Kazı Performanslarının Optimizasyonu. TÜBİTAK Rapor No 105M017, 224s.

[7] Yeşilkaya, L., Ersoy, M., Çelik, M., Çatalpınar, A., 2009. Kaklık-Denizli Traverten Ocağında Zincirli Kollu Kesicinin Kullanımının Araștırılması. Madencilik Dergisi, Eylül. 48(3), 33-43.

[8] Sarışık, A., Sarışık, G., 2010. Efficiency Analysis Of Armed-Chained Cutting Machines In Block Production In Travertine Quarries. Journal Papers, 110, 473-480.

[9] Çopur, H., Balcl, C., Tumac, D., Bilgin, N., 2011. Field And Laboratory Studies On Natural Stones 
Leading To Empirical Performance Prediction Of Chain Saw Machines. International Journal of Rock Mechanics and Mining Sciences, 48(2), 269-282.
[10] Yeşilkaya, L., Ersoy, M., Çelik, M., Kayı, Z., 2017. Mermer Ocaklarında Elmas Tel Kesme ve Zincirli Kollu Kesme Makinelerinin Birlikte Kullanımının İncelenmesi. Politeknik Dergisi, 20(2), 459-473. 